\section{Congress tackles 1983 budget}

\section{Close vote on}

\section{science budget}

\section{a surprise}

\section{Washington}

In the first congressional action on the research and development budget for the fiscal year 1983 submitted by President Reagan at the beginning of February, a subcommittee of the House of Representatives Science and Technology Committee agreed by one vote last Thursday to recommend that the budget for the National Science Foundation (NSF) be increased by $\$ 30$ million over the President's request to a total of $\$ 1,099.5$ million.

The subcommittee left untouched the proposal to spend $\$ 1,052.3$ million on "research and related activities" sponsored by NSF, although it has suggested some reshuffling between categories. For example, it suggests cutting from 9.5 to 5.6 per cent the proposed increase in funding for mathematical and physical sciences, and that biological, behavioural and social sciences should grow by 14.2 rather than 6 per cent, particularly in the light of the major cuts in social science research last year.

The subcommittee has also proposed transferring some of the funds for research to support the International Institute for Applied Systems Analysis in Vienna. However, the Reagan Administration's decision to eliminate its contribution to the institute, originally taken last year but since reconsidered, is said to have been made final at a meeting of the National Security Council last week.

The main difference between the subcommittee's and the Administration's proposals are over NSF support for science education. Whereas the Reagan Administration, committed to phasing out such activities within NSF, has proposed a budget of $\$ 15.0$ million in 1983 - down from $\$ 70.7$ million in 1981 - the members of the subcommittee have registered their opposition by adding another $\$ 30$ million.

It was primarily this decision that led the Republican members of the subcommittee, as well as newly-elected Democrat Dave McCurdy of Oklahoma, to vote against the proposed increases. Disagreement over the science funds is also expected to generate another close vote in the full science committee when the budget authorization bill comes up for approval.

The closeness of the vote, especially among the members of what is generally considered to be one of the most proscience subcommittees in Congress, suggests that the final figures for government support of research and development next year are likely to be close to those submitted by President Reagan, since Democrats seem reluctant to ask for major increases in the science budget and Republicans are reluctant to demand major decreases.

According to a preliminary analysis of the Administration's budget request released last week by the American Association for the Advancement of Science (AAAS), the net result of the request would be to increase research and development spending by 2.2 per cent in real terms over 1981 to $\$ 44,400$ million.

Within this total, basic research will increase from $\$ 5,100$ million in 1981 to $\$ 5,900$ million in 1983 , an increase of 14.9 per cent in current dollars, but a decrease of 1.3 per cent in constant dollars. The AAAS analysis demonstrates clearly that the expansion of research budgets is almost entirely explained by the growth of military-supported research.

Much grousing has been heard on Capitol Hill over the past few weeks as different committees have held hearings on the Administration's proposed budget. Some of the loudest have come from members of the space science community where, although major projects such as the Galileo mission to Jupiter have retained support in an overall budget that increases by 28 per cent between 1981 and 1983 , several research programmes will still have to be terminated.

Quoting examples such as the decision to close the lunar curatorial facility, the main centre for the analysis of Moon samples and cosmic dust collected by the Apollo missions, as well as to shut down the transmission and reception of data from Pioneers 10 and 11, launched in the mid-1970s and still sending data from deep space, the planetary sciences division of the American Astronomical Society has released a statement claiming that the Reagan budget would devastate planetary research at the National Aeronautics and Space Agency.

A strong critic of the Administration's proposals for energy research has been Dr John Deutch, who was director of the Department of Energy's Office of Energy Research for the first two years of the Carter Administration, and is now dean of science at the Massachusetts Institute of Technology. Dr Deutch told a Senate subcommittee last week that the proposed cuts in energy research and development supported by the federal government would have a damaging effect on the nation's future energy supply. The private sector could not be expected to undertake all necessary research and development in energy, said Dr Deutch: "a policy based on this assumption places our technical future in energy technology at risk".

Whereas the Administration is planning to cut support for coal research and development from $\$ 500$ million in 1982 to $\$ 84$ million next year, Dr Deutch suggested it should be raised to $\$ 625$ million. In contrast, rather than asking for $\$ 557$ million for the support of breeder reactor systems research, he suggested cutting this back by $\$ 125$ million and abandoning the proposed liquid metal fast breeder reactor at Clinch River in Tennessee, which he described as "unneeded and technically obsolete".

The most important factor determining the final outcome of the science budget will be the broader political debate on how much of a federal deficit the nation's economy can tolerate. If Congress decides that the proposed deficit is too large, but is reluctant to cut back on demands for increased military spending (or to increase tax revenues), then it will be looking for more cuts in the civilian budget. Whether this will be necessary depends on deliberations within the budget committees of the Senate and the House of Representatives that will be taking place over the next two months.

David Dickson

\section{Glenn speaks out}

One of the strongest critics of the Administration's policies towards the support of research and development is Senator John Glenn of Ohio who, like Senator Harrison (Jack) Schmitt, the chairman of the Commerce Committee's science and technology subcommittee, was a member of NASA's early astronaut team.

Senator Glenn has been addressing scientific and engineering societies, in

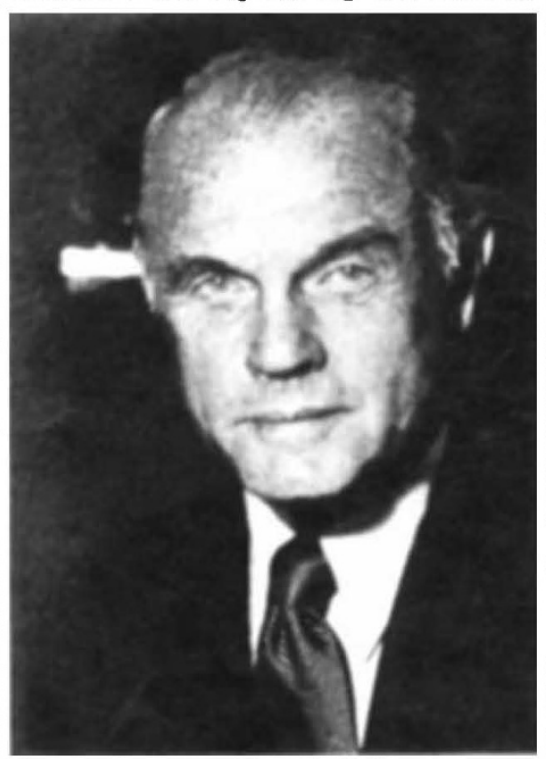

Glenn - from spaceship to White House?

particular advocating strong unilateral measures to prevent the proliferation of nuclear weapons through controls on nuclear exports. He is also expected to be a candidate for the Democrat presidential nomination in 1984, offering an alternative vision of liberalism to those of Senator Edward Kennedy and former vice-president Walter Mondale. 